\begin{tabular}{|c|c|}
\hline & $\begin{array}{l}\text { International Journal of Trend in Scientific } \\
\text { Research and Development (IJTSRD) }\end{array}$ \\
\hline 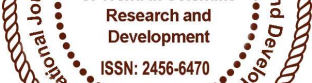 & International Open Access Journal \\
\hline 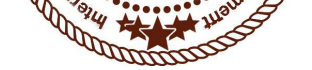 & ISSN No: 2456 - 6470 | www.ijtsrd.com | Volume - 2 | Issue - 2 \\
\hline
\end{tabular}

\title{
Appraising Capability Models for Conceptualising the Development of Competencies amongst Students of the Higher Technical Teachers' Training College (HTTTC), Kumba
}

\author{
Massa Ernest Massa M.Ed. \\ Ph.D, Fellow, Department of Educational Foundation and Administration, \\ University of Buea, Cameroon
}

\section{ABSTRACT}

Notions of competency have dominated the teacher education literature, and have underpinned Competency-Based Training in educational leadership at all levels of education and training. The emergence of counter-narratives underpinned by the capability movement, have as yet had minimal impact on practice in teacher education. New discourses in educational theory and practice which are founded on non-linear approaches to learning and teaching provide added impetus to engage in the competency/capability debate, and re-examine our approaches to educational leadership. This paper explores complexity theories and demonstrates how complexity's pedagogical implications can lead to new models for understanding educational leadership learning and teaching. A new model for conceptualizing end-user educational leadership is presented that was derived from a three-year action research initiative with pre-service teachers. The premise of the study assumed that there is no relationship between the capability approach and the development of students' competencies in the Higher Technical Teachers' Training College Kumba. The study had as specific objectives to identify the teaching and learning strategies used, examine the use of the Capability approach in the development of competencies of students and the challenges faced by both the students and teachers in the implementation of the capability approach in developing competencies in the Higher Technical Teachers' Training College Kumba. The sample constituted 190 questionnaires administered to the students of HTTTC Kumba and 5 interviewed conducted with teachers of the school. The findings of this study showed that teachers of the HTTTC Kumba highly implement group discussion, brainstorming and demonstration whereas role play and lecture/presentation methods are only implemented to a lesser extent. Findings also showed that the students have the freedom and are guided towards what they are best at doing but for the fact that resources are insufficient to facilitate the implementation of this approach. The spearman rank correlation was 0.586 indicating a strong positive relationship between the use of the capability approach and the development of students' competences in HTTTC Kumba. The study concluded in favour of Sen's findings that technical education today is the most valuable means by which the quality of a country's development is determined. This is because capable people are more likely to be able to deal effectively with the turbulent environment in which they live by possessing this 'all round' capacity. The important practical point stressed here however was that the development of core competences by students could lead, as a secondary effect, to a more sustainable and democratic society. As such, inferences was drawn that for Cameroon to become Emerging by the year 2035 competency development in Technical Education need to be given adequate attention. 
Keywords: Appraising Capability Models, Development Of Competencies, Students, Higher Technical Teachers' Training College, (Httc) Kumba

\section{INTRODUCTION}

While recent studies (for instance, Knezek \& Christensen, 2000; Warner, 2000) document growing levels of educational leadership among school students, there are still many mature-aged individuals, as well as many school leavers, who are insecure in their computer use. For this reason, educational leadership and training in the use of reflective skills will continue to be a significant issue for business, industry, and educational contexts alike (Watson, 1997). There is little research or documentation that discusses the teaching strategies employed in educational leadership and training. Many teacher training programs are directive in nature, guiding participants through a series of step-by-step instructions and focusing on one particular program. Certainly, educational contexts such as the Higher Technical Teachers' Training College Kumba, which draw on competency-based approaches to learning, tend to be highly structured and directive, teacher centred rather than learner focused and, more often than not, have a "poor rate of return. These approaches might be contrasted to observations of the ways in which many individuals who become proficient at using acquired competencies, namely through self-directed exploration, as opposed to short courses or training sessions (Davis, 1999).

\section{BACKGROUND TO THE STUDY}

In the light of globalization and the resulting increased global competition as well as the global shift towards knowledge based economy, Thurik (2009) claim a major shift away from the managed economy towards a so-called entrepreneurial economy. While the managed economy was characterized by large firms which promoted economic growth through their economies of scale and routinized production, the entrepreneurial economy is driven by the flexibility, diversity and innovativeness of new firms (Thurik, 2009). Yet, in order to have an economy where there high entrepreneurial spirit, there must be a shift from general education to a more technical and vocational based education. This seems to be the shift in the Cameroonian economy. Capability approach is based on competencies development. In recent years, Technical Teachers' Training Education has become the lifeblood of Cameroon in that, it is the sector that produces manpower needed by the economy hence, contributing greatly to socio-economic development. The main aim of education is not knowledge. Tambo (2012) defines education as the sum of a person's learning experiences during his or her lifetime. This study is the capability approach and the development of competencies in the technical teachers' training college. Amartya Sen's Capability model holds that, for competencies of writing, reading and being able to do other skills to be developed or achieved; those involved must be free to do what they desire so as to value what they are able to do at the end. One of the most recent models to challenge traditional concepts of learning and which looks at outcomes as well as process is that of Capability (Stephenson \& Weil, 1992).

The capability approach is a broad normative framework for the evaluation of individual well-being and social arrangements, the design of policies and proposals about social change in society. The capability approach is used in a wide range of fields, most prominently in development thinking, welfare economics, social policy and political philosophy. In academia, it is being discussed in quite abstract and philosophical terms, but also used for applied and empirical studies (Fukuda-Parr and Kumar, 2003).In the application of capability approach in the school systems, it calls curricula which do not only inform, but transform learners into more suited participants in their immediate community. This concept could be better applied in Technical education which is particularly designed with this goal in mind. The core characteristic of the capability approach is its focus on what people are effectively able to do and to be, that is, on their capabilities. A focus on student's capabilities in the choice of developing their skills makes a profound theoretical difference, and leads to quite better involvement from the students and effective development of their skills which can better lead to an emerging Cameroon.

Capability approach can be traced back to, among others, Aristotle, Adam Smith, John Stuart Mill and Karl Marx (Nussbaum, 1988; Sen, 1993) but the approach in its present form has been pioneered by the economist and philosopher Amartya Sen (Sen, 1980; Sen, 2002) with more recent significant contributions from Nussbaum (2003). Sen argued that in social evaluations, skills development and policy design, the focus should be on what people are able to do and be, on the quality of their life, and on removing obstacles in their lives so that they have 
more freedom to live the kind of life which, upon reflection, they find valuable. He stated that:

"The capability approach to a person's advantage is concerned with evaluating it in terms of his or her actual ability to achieve various valuable functionings as a part of living. The corresponding approach to social advantage -for aggregative appraisal as well as for the choice of institutions and policy takes the set of individual capabilities as constituting an indispensable and central part of the relevant informational base of such evaluation" (Sen, 1993).

Throughout the world, and particularly in Sub Saharan African countries, governments are renewing efforts to promote technical and vocational education and training (TVET) with the belief that skill formation enhances productivity and sustains competitiveness in the global economy. According to Bhuwanee (2006), concerns have been raised by most African countries recently about the move towards making Technical and Vocational Education Training complementary to post basic education. Competency based approach and the explicit methods have been a way forward to solving the technical education problem. Technical education is gradually gaining roots in the world today and Africa and Cameroon are not left out. And because of this, many approaches have been put in place to ensure the quality of education. Such approaches include; competencybased approach, New Pedagogic Approach and the Explicit Teaching Approaches. The process of building the Higher Technical Teachers' Training Colleges (HTTTC) in Cameroon is bringing radical change to the form and content of courses in the Universities. Throughout this process, a key concept is that of "competencies". Competence approach is playing a fundamental role, and is being used to design new syllabuses to enable comparability throughout Cameroon by standardizing the way students' performances is assessed.

There have been repeated calls from Governments, business world and others in Cameroon for reform of Technical education, methods and skill training through the 1995 Forum on Education. These proposals were later outlined in the "Guidelines for education in Cameroon". Law No: 98/004 of 14th April 1998. The need for such reform is now more urgent than ever, given the ambitious programme for the country to attain emergence by 2035 . The importance of developing a more highly skilled and adaptable workforce is now widely recognized. The process of building the Technical Education sector is bringing radical change to the form and content of subjects taught at the Higher Technical Teachers' Training and Technical secondary schools and colleges in Cameroon. The organization of studies (duration, depth of coverage, amongst others.) and the content (what is taught and how) have been transformed, based on the following three premises: comparability between studies from other Technical schools, mobility of students and teachers, and cooperation for quality education. Considering Cameroon's vision of emergence by 2035 , recent calls for further reform of Technical education and training arrangements in Cameroon have drawn attention to competency-based Approach (CBA). Teachers of technical Education therefore needs to be adequately informed on these methods and how they operate.

The introduction of the competence based approach (CBA) falls in line with the recommendations of the National Forum of Education. The recommendations of the Forum became the substance of Law No. 98/004 of April 14, 1998 to lay down guidelines for education in Cameroon. According to this law, the general purpose of education at the levels of primary and secondary education shall be to train children for their intellectual, physical, civic and moral development and their smooth integration into society bearing in mind prevailing economic, socio-cultural, political and moral conditions. With the introduction of the 1998 law, the pedagogic service of the Ministry of Secondary Education embarked on a careful examination of the limitations in the existing teaching methods in primary schools. This orientation generated a popular phrase, "the new pedagogic approach" (Tambo, 2000).

The competence-based approach (CBA) as childcentred approach to teaching is not really new. "The expression competence based approach can be understood as a slogan adopted by MINESEC to mobilize teachers to shun outmoded practices and embrace pedagogic renewal (Tambo, 2003)". The importance of this perspective on development is emphasized recently by the United Nations. Being educated has been described by Sen as the enhancement of people's freedom to do and be what they have reason to value (McCowan, 2011). The idea of a person in the Capability Approach is one of having a wide range of valued 'doings and beings' (Unterhalter, 2008). The capability approach is used 
in a wide range of fields, most prominently in development thinking, welfare economics, social policy and political philosophy. It can be used to evaluate a wide variety of aspects of people's wellbeing, such as individual well-being, inequality and poverty. It can also be used as an alternative evaluative tool for social cost-benefit analysis, or to design and evaluate policies, ranging from welfare state design in affluent societies, to development policies by governments and non-governmental organisations (NGOs) in developing countries. In academia, it is being discussed in quite abstract and philosophical terms, but also used for applied and empirical studies. In development policy circles, it has provided the foundations of the human development paradigm (Fukuda-Parr, 2003; Fukuda-Parr and Kumar, 2003). The core characteristic of the capability approach is its focus on what people are effectively able to do and to be, that is, on their capabilities.

Capability approach is a broad normative framework for the evaluation and assessment of individual wellbeing and social arrangements. According to this approach, welfare and quality of life are identified with people's satisfaction, where greater satisfaction means greater happiness. But this utilitarian approach, which concentrates on individual happiness or pleasure, does not contemplate other aspects of development; nor does it address the inequalities and differences between human beings (Sen, 1987). One of Sen's major contributions is that he has helped to direct attention to other kinds of considerations when we talk about development, well-being and quality of life. The achievement of universal education and especially technical Training is also one of the Millennium Development Goals (United Nations Children's and Education Fund, UNICEF, 2003). The 1998 law to lay down guidelines for education in Cameroon which states that "the state shall guarantee the right of every child to quality education" is just another factor to back up the necessity of education in Cameroon and Technical education in particular. The need for reforms has been a consistent theme within Cameroon's educational policy. For example, the report of the 1995 National Education Forum and the Draft Document of the Sector-Wide Approach to Education and most recently, the sustainable development goals. These important documents point out the need to develop skills and knowledge in the Students.
The creation of the Higher Technical Teachers' Training College required the incorporation of a range of concepts and techniques to standardize academic curricula. The Higher Technical Teachers' Training College Kumba was created by decree number 2014/090 of 07 May 2014. The Higher Technical Teachers' Training College is found in Kumba, Meme Division of the South West Region of Cameroon. The main theory of this study is the capability theory developed by Amartya Sen. The theory will serve as a model for examining competencies developments in the Higher Technical Teachers' Training colleges and secondly, what capability approach is and whether they are being applied in Technical Training Institutions in Cameroon. Amartya Sen's Capability model holds that, for the objective of any institution introduced to be achieved; those involved must be free to do what they desire so as to value what they are able to do at the end. This is one of the most recent models to challenge traditional concepts of learning and which looks at outcomes as well as process. That is, the resources available in the process of learning (Stephenson \& Weil, 1992).

An important category in the capabilities approach is "functioning". 'Functioning' can be (1) activities like reading or writing; (2) physical states, such as being well-nourished and healthy; (3) mental situations, like being happy, or (4) social functioning, such as being integrated into society. When people have managed to perform a set of functioning, it seems logical to think that they have faced a number of possibilities and opted for those that they considered to be the most appropriate for their wellbeing. This theory was first introduced in 1979 by Amartya Sen in his article "Equality of What?" (Sen, 1979), which focuses on the freedom people really have to conduct their lives in ways that they have reason to value. The focus of the capability approach lies in the freedom that a person actually has; not merely in the evaluation of the situation by an external body. Capable people are those who: know how to learn; are creative; have a high degree of self-efficacy; can apply competencies in novel as well as familiar situations; and work well with others. The main competences here is that of learning how to teach and be able to develop practical skills in the use of tools such as computers, In comparison to competency, which involves the acquisition of knowledge and skills, capability is a holistic attribute. Application of the capability concept has largely involved the creation of innovative learning experiences that help develop the 
elements of capability in individuals (Graves, 1993; Stephenson, 1994; and Stephenson \& Weil, 1992) in both education settings and in the workplace.

\section{STATEMENT OF THE PROBLEM}

Focusing on capabilities can explain what it means to be educated in the global era and ensuring freedom in developing competencies of students which is the problem with the educational system today. The challenge to education generally has been that, traditional education systems are rigid and designed to produce a cream of privileged elites. This was the case in Cameroon where the post-independence education system with its grammar school orientation was designed to produce an educated class that would take over from the colonial administration. However, this white-collar mentality is gradually phased out with most governments recognizing the need for educational flexibility and technically equipped workers to boost economic growth. In this regard, the Government has made every effort to valorise technical education in Cameroon. This has been done firstly, by creating more of the technical training colleges in Cameroon. With the creation of these technical training institutions, the worry is that many students still leave the training schools with little or no mastery of the teaching methods. The students are therefore expected to become practical in their teaching skills, be able to manipulate tools such as; control devices (contactors, switches, push button), line breakers, protecting devices, computers, web design, draft business correspondences, duplicators just to list a few. The study is therefore aimed at examining whether the higher technical teachers' training college Kumba is providing flexible programmes and resources that will satisfy the desires of the students as they graduate, whether the learning approaches or training strategies used are such that their teaching skills can be developed and also to examine if there exist a relationship between capabilities approach and the development of competencies of students of the Higher Technical Teachers' Training College Kumba.

\section{OBJECTIVES OF THE STUDY}

This study is aimed at examining the capability approach and the development of competencies of Students of the Higher Technical Teachers' Training College Kumba.

\section{SPECIFIC OBJECTIVES}

The specific objectives of the study will be to:
$>$ Identify the learning strategies used in the process of developing the competencies of students as per capability approach in the Higher Technical Teachers' Training College Kumba.

$>$ Examine the use of the Capability approach in the development of competencies of students in the Higher Technical Teachers' Training College Kumba.

$>$ Examine the challenges faced by both the students and teachers in the implementation of the capability approach in developing competencies in the Higher Technical Teachers' Training College Kumba.

\section{RESEARCH QUESTIONS}

The following research questions will guide the study What are the teaching and learning strategies used in developing competencies of students as started by capability approach in the Higher Technical Teachers' Training College Kumba? How is the Capability approach used in the development of competencies of students in the Higher Technical Teachers' Training College Kumba?

What are the challenges faced by both the students and teachers in the implementation of the capability approach in developing competencies in the Higher Technical Teachers' Training College Kumba?

\section{THEORETICAL PERSPECTIVES}

\section{The Capability Theory by Amartya Sen (1993)}

Sen's capability approach was developed as a framework to analyze different concepts in welfare economics, including standard of living, personal well-being, quality of life, competence development, educational attainment and poverty. Standard of living is traditionally measured by the ability to buy a basket of commodities. Sen refers to this approach as the opulence view. Standard of living is also measured in terms of utility, where utility is meant as pleasure and happiness, or as a tool for valuation and choice. Sen argues that the standard of living concept encompasses more aspects than the opulence and the utility measures. Under the capability approach, Sen focuses on the type of life that people are able to live, that is, on their capability to achieve or accomplish, on what they succeed in being or doing. The possession of commodities is valuable only to the extent that it enables the person to do or be a range of 
things. A commodity is considered to have "characteristics." For instance, for a person with a spinal cord injury, a wheelchair has the characteristic of providing transportation; it does not have such a characteristic for a person who can walk.

In Sen's approach, capability means "practical opportunity." The ordinary meaning of functioning is an activity, something a person does. In Sen's approach, functioning has a broader sense; it includes activities as well as desirable states, such as "being well nourished" or "being free of malaria." Sen illustrates the difference between capabilities and functioning through the example of two people who are starving. They achieve the same functioning, malnourishment, but they have different sets of capabilities. One is starving due to religious faith; she has decided to starve, whereas the other is starving from poverty. Capable people are those who know what to learn, how to learn; are creative; have a high degree of self-efficacy; can apply competencies in novel as well as familiar situations; and work well with others. In comparison to competency, which involves the acquisition of knowledge and skills, capability is a holistic attribute. The world right now is no place for the inflexible, the unprepared, and the ostrich with head in sand; and this applies to organisations as well as individuals. Capable people are more likely to be able to deal effectively with the turbulent environment in which they live by possessing this 'all round' capacity.

Application of the capability concept has largely involved the creation of innovative learning experiences that help develop the elements of capability in individuals (Graves, 1993; Stephenson, 1994; and Stephenson \& Weil, 1992) in both education settings and in the workplace. More recently, in Australia, we have been interested in not only how work based learning can develop capable people, but also how human resource management and development systems may also be designed to enable capability in everyday work (Cairns \& Hase, 1996; Hase, 1998).

\section{Theory of Justice on Capability Approach}

A number of philosophers sympathetic to Sen's foundational concerns have nevertheless been dissatisfied with the vagueness and under-elaboration of the theoretical structure of his Capability Approach (although these features seem to be quite deliberate on Sen's part). A number of theoretical accounts have been developed that seek to elaborate the Capability
Approach more systematically and to address these philosophers' particular concerns. Some theoretical accounts are primarily concerned with operationalising the evaluative dimension of the Capability Approach: the assessment of quality of life, well-being and human development. Others focus on developing a capability based 'Theory of Justice' in the spirit of its concerns.

A Participatory Approach to Evaluating Capability Expansion (Sabina Alkire) Sabina Alkire has developed a philosophically grounded framework for the participatory valuation and evaluation of development projects in terms of capability enhancement (Alkire, 2005). This allows her to go beyond standard cost-benefit analyses of development projects in financial terms to investigate which capabilities that the people concerned have reason to value are enhanced and by how much. To Alkire, she believes that for an individual to value what he or she chooses is based on an evaluation of what that individual put in and what that individual is getting out of the training.

In this light, Mbua (2002) defines cost - benefit analysis approach as "the systematic comparison of the magnitude of the costs and benefits of some form of investment in order to assess its economic profitability". That is, providing a measure of expected yield of the investment as a guide to efficient allocation of resources. As a result, this approach is costs and benefits oriented and emphasis is placed on limited resources. This study does not look at capability from the cost-benefits approach but from the level of competencies, that is, the level at which the students are equipped with the knowledge, skills and attitude in becoming teachers in the ministry of secondary education. As earlier mentioned, this study is not out to look at the material benefit student teachers leaving the Higher Technical Teachers' Training College will achieve but on the contrary, how able are they to fit into the teaching profession.

\section{LITERATURE REVIEW}

\section{Capability Approach and Competencies} Development

The concept of capability approach has been viewed from different perspective or disciplines by different philosophers and scholars. According to this approach, welfare and quality of life are identified with people's satisfaction, where greater satisfaction means greater happiness. But this utilitarian approach, 
which concentrates on individual happiness or pleasure, does not contemplate other aspects of development; nor does it address the inequalities and differences between human beings (Sen, 1987). One of Sen's major contributions is that he has helped to direct attention to other kinds of considerations when we talk about development, well-being and quality of life.

\section{Freedom as the Main Capability Philosophy}

Sen explained: "While the combination of a person's functionings reflects her actual achievements, the capability set represents the freedom to achieve: the alternative functioning combinations from which this person can choose" (1999). As affirmed above, Sen used this concept for the first time in 1979. He introduced this concept in the Tanner Lecture "Equality of What?" in order to present an alternative of evaluation of equality distinct from the Utilitarian and the Rawlsian views. In that lecture he spoke of "basic capability equality", "a person being able to do certain things" (1980: 217)-the recalls it in 1993. He then considered basic capabilities as a refinement of Rawls' concentration on primary goods to evaluate equality (an element of "goods fetishism"). His aim was to do the most possible complete evaluation.

We have to pay attention to what a person can do rather than what a person does (1980-1: 209). When he added the concept of functioning he defined the capabilities of a person in relation to them as the "set of functioning vectors within his or her reach" (1985: 201). He realized that both concepts were intimately related, because the extent of the capability set is relevant to the significance of functioning. He provided a more formal treatment to these concepts in Commodities and Capabilities of 1985 (1999). The valuable functioning's achieved, constitutive of a life, only pertain to each particular person. There is, thus, a triple heterogeneity within society: singular diverse persons contribute to well-being performing their proper ends thanks to the resources that they have. We have a plurality of person, of ends of these persons and of means. Thus, wellbeing supposes choices and consequently, freedom. Freedom is thus present everywhere. Sen conceives development as a process of expanding the real freedoms (1999). Human capability is an expression of freedom (Sen 1999). As Crocker points out, "capabilities add something intrinsically and not merely instrumentally valuable to human life, namely, positive freedom" (Crocker, 1995: 159; see also 183). Positive freedom is what people are actually able to do or to be, "to choose to live as they desire". In a further section some criticisms that Sen received for a supposedly overestimated and under-elaborated notion of freedom. In any case, his notion of freedom goes beyond the classical liberal conception of freedom, namely, negative freedom.

\section{The Development of Competencies in the Higher Education using Capability Approach}

Lozano ( 2007), In parallel to the conceptual development of the capabilities approach and its relation to the field of education, the concept of competence has acquired remarkable importance in higher education worldwide and very clearly within the European Union and the United States ("Workplace competencies"). This is so to the extent that today the notion of competence and skills is guiding the development of undergraduate and postgraduate syllabuses throughout the process of building a common European Higher Education Area The creation of a European Higher Education Area has required the incorporation of a range of concepts and techniques to standardize academic curricula. Moreover, $n$ whereas previously undergraduate education was intended to provide students with the general foundations of a discipline, the emergence of lifelong learning and the theory of human capital (Becker, 1993) have changed some basic assumptions. This has led to a conception of Higher Education as a process which advances in people a capacity to update their knowledge continuously to adapt to the needs of their jobs and the market. Consequently, conceptions of education today frequently place a heavier emphasis on the development of specific skills than on the development of the whole human being (Slaughter \& Leslie, 1997; Hinchliffe 2002; Walker, 2003).

Technical education today is the most valuable means by which the quality of a country's development is determined. In parallel to the conceptual development of the capabilities approach and its relation to the field of education, the concept of competence has acquired remarkable importance in technical Training worldwide and very clearly within the African Union and Cameroon inclusive. This is so to the extent that today the notion of competence and skills is guiding the development of undergraduate and postgraduate syllabuses throughout the process of building a common technical Education Area (Boni \& Lozano, 2007). To fully enhance freedom and development as expressed in the Capability Approach, education must 
move from rote learning towards specifically addressing the development needs and aspirations of the individuals, their ability to think and reason, build up self-respect, as well as respect for others, think ahead and plan their future. The importance of such mental power, that is, cognitive, emotional and social abilities, is making its way into education policies and plans, often under the name of life skills. This term appeared early in the field of health promotion where it was recognized that people cannot achieve their fullest health potential unless they are able to take control of what determines their health (WHO, 1986). Life skills were seen as the abilities for adaptive and positive behaviour that enable individuals to deal effectively with the demands and challenges of everyday life.

The creation of the Higher Technical Teachers' Training College required the incorporation of a range of concepts and techniques to standardize academic curricula. Moreover, whereas previously graduate education was intended to provide students with the general foundations of a discipline, the emergence of lifelong learning and the theory of human capital (Becker, 1993) have changed some basic assumptions. Technical education is the most valued today and this can be seen in the many changes introduced to improve on quality, relevance, and ensure equality. The provision of technical education is one of the fundamental human rights (UNESCO, 2002). The achievement of universal education and especially technical Training is also one of the Millennium Development Goals (United Nations Children's and Education Fund, UNICEF, 2003). The 1998 law to lay down guidelines for education in Cameroon which states that "the state shall guarantee the right of every child to quality education" is just another factor to backup the necessity of education in Cameroon and Technical education in particular. The need for reforms has been a consistent theme within Cameroon's educational policy. For example, the report of the 1995 National Education Forum and the Draft Document of the Sector-Wide Approach to Education. These important documents point out the need to develop skills and knowledge in the Students.

Throughout this process a key concept is that of "competencies". Although there is no specific definition of the concept of competencies, the competencies approach is playing a fundamental role, and is being used to design new syllabuses to enable comparability throughout Europe by standardising the way student performance is assessed. It is therefore, fundamental to provide a philosophical analysis of the meaning of competence and to explore the educational model that underpins this proposal. Although it is not essentially a philosophical document, it is basically followed for two main reasons: It is one of the more inclusive and detailed studies of key competencies in the domain of education; and second, it is widely recognised and availed of around the world in evaluations of basic education and higher education.

The capabilities approach has been much studied and used in the field of development study (Sen, 1999; United Nations Development Programme 1990-2008), and we believe it has much to offer from the standpoint of educational theory and practice, as shown by the explorations of Nussbaum (2006), Unterhalter (2007), and Hinchliffe (2009). The capability approach, sometimes called the human development capability approach or capabilities approach has been used in many academic disciplines and different people, organizations, students and public officials have looked to this framework to see how it could better people's lives. However, the challenge is that scholars from different disciplines approach the capability approach using their disciplinary lenses. This has at times led to misunderstandings because of the different ways of approaching the capability approach framework. An understanding into the concepts used in the Capability Approach could help readers to get a better understanding why the framework has attracted the attention of many people from different disciplines, organizations and places of work.

\section{EMPIRICAL REVIEW}

Gries and Naudé (2011) examined the "Empowerment of entrepreneurs: application of Amartya Sen's capability approach to improve the livelihood of artisans in India" uses a country- and sector-specific framework conditions when it comes to entrepreneurship in the artisan sector in India. The study made used of six expert interviews with academic as well as business professionals in a first interview wave and 15 interviews with rural as well as metropolitan artisans in a second wave of interviews. The fundamental finding of this thesis is that the entrepreneurs of the analyzed target group cannot be categorized as solely necessity- or opportunity-driven. Instead, the artisans combine typical character traits and attitudes of both. This study concluded that a great demand for further research and encourages more extensive research projects that analyze the 
relationship of entrepreneurial activity and experienced life quality as well as economic empowerment of artisans in India as well as indicators to stimulate the same.

Crocker, (2008) contend that the capability approach provides a better framework for thinking about human well-being and development than more traditional approaches which typically focus on utility or resources. In his study illustrated by drawing on the results of a survey which investigated how ordinary people in South Africa view human well-being (a 'good' form of life). However, the results of this exercise indicated that the capability approach overlaps with both utility (happiness, pleasure, etc) and resource-based concepts of well-being. The distinctions between commodities (and their characteristics), human functioning and utility is less robust than Sen implies. In particular, the capability approach needs to make more space for the role of utility and say more about the material basis of wellbeing.

Bonvin \& Farvaque (2006), argued that the capability approach affects evaluation on II two l/ levels: 'substantial' and 'procedural'. The substantial level involves the actual information sets on which we base our evaluations, which are in turn driven by the kinds of questions that we have asked and the procedural level the processes involved in deciding on the information sets and gathering the information required. With respect to the substantial level, Bonvin $\&$ Farvaque (2005) argued that the information on which we base our evaluations "is not neutral" as decisions are made during evaluations as to what we are to measure and the information sets that are to applied to these measures and, by virtue of this, as to what we are not going to measure and the information sets that are not to be included. Core to the 'substantial level' of evaluation, and as discussed above, is the importance of human flourishing evaluated through the notions of 'capabilities', 'functionings' and 'freedom'. Tikly explains that "from a human capabilities perspective, this suggests that "evaluation of VET systems whilst important needs to be evaluated against a more holistic set of criteria"

Bruffee (2012) conducted a study in Uganda which included 35 semi-structured in-depth expert interviews, five group discussions and eight observation reports have been carried out. 20 of the interviews provide insights in Uganda's education system and the impact of the curriculum implementation process of the Thematic Curriculum. Additionally, 15 of the interviews, the group discussions and the observations support the case study on the area of Namasale Sub-County, Amolatar District, and Northern Uganda. The data from Namasale Sub-County is supported with secondary data from a participatory needs assessment of DevEd conducted and consisting interviews and group discussions with 434 respondents from the Namasale Sub-County. The case study area is used to explore the use of the School Development Index to examine the teachers' and students' capabilities that support or hinder the quality improvement that is intended with the introduction of the Thematic Curriculum in 2007. The results of this study show that the constructs of implementation are insufficiently fulfilled to achieve the intended quality improvement. The general profile of implementation of the Thematic Curriculum suggests that it is good in theory, but is not good enough in practice. The initiated changes that are part of the Thematic Curriculum are generally perceived as positive development, but in practice they are inadequate to address the challenges faced in public primary education. Especially the rural areas are confronted with a complex puzzle of a lack of resources, unmotivated teachers and the absence of legitimate support to counter their challenges. Moreover, the input and outcome indicators of the quality of education show that the quality of education has not improved sufficiently since the introduction of the Thematic Curriculum in 2007. These indicators are analysed, but it is argued that large regional disparities are not taken into account. Subsequently, the application of the SDI to the selected research area - Namasale Sub-County - shows that the situation with regards to the teachers' and students' capabilities is genuinely poor. The selection of indicators for the capabilities, ranging from basic survival capabilities to students' capability to access appropriate pedagogies, is a debateable attempt.

Custers (2015) Following Sen and Nussbaum adopted capabilities as a metric for making quality of life comparisons. Capabilities reflect the real freedom or opportunities people have to achieve functionings. Hypotheses tested employing multilevel models, using data from the European Quality of Life Survey (EQLS) covering 31 countries. First, a factor analysis demonstrated that multiple capability subdimensions can be reduced to single latent dimensions, implying that some of Nussbaum's capabilities overlap. 
Second, the multilevel analyses indicated that education and income are pivotal in developing and maintaining at least some capabilities. Social and healthcare spending work as an important fail-safe to prevent people from capability deprivation. Furthermore, the (theoretically distinct) capabilities sense, imagination and thought; practical reason; emotions; affiliation; and bodily health are all important in explaining wellbeing, thereby indicating the general importance of these capabilities. Outlier and robustness analyses are performed to validate the findings concerning capabilities and wellbeing. Finally, this study introduced the application of a full explanatory model in the capability literature. In line with research from Anand and colleagues it showed that the Capability Approach provides a feasible framework for making quality of life comparisons based on data from household surveys.

This study argues that human capital and human rights constitute parts of human development capability approach (HDCA). There is also a strong notion of aspiration to make HDCA practical to solving problems of poverty, deprivation, unfreedoms and ignorance. Since the study was to see how the essential elements of the EHDCA interrelate, concepts used in EHDCA were defined to help readers understand the model suggested in this study. The final section is on the implications of the EHDCA to secondary education TVET policy in Uganda. It is important to mobilize a person's resources, aspirations, capabilities, expressed in agency, that lead to the enhancement of capability and aspiration sets to enable a person to achieve valued freedoms, which is the goal of EHDCA model. Human capital and human rights approaches are not distinct but form part of the HDCA. The understanding of the essential elements of EHDCA helps us to conceptualize education especially among the deprived populations. The study brings in the understanding of the evolution of the concepts of aspirations and capabilities in the academic field. Finally, the study provides conceptual materials for partners in education to conceptualize education.

Cameroon cannot do much to improve the productive capacity of their populations when the education systems are elitist and suffer from other intervening factors such as lack of resources, bureaucratised nature of education, poor teaching methods. In addition, the curricula of the technical education do not respond to the competitive factor market. This study is important in that it will bridge the gap between the technical education and competencies development, the gap between teaching methods and competencies development, the gap between the resources and the development of competencies and bridging the gap between education and the job market. Literature reveals that students from primary/elementary to University acquire few skills and knowledge to exploit opportunities in the job market, hence leading to high unemployment especially among the young population. This is particularly true as occupations become highly specialized. This situation implies that policy makers have done little to create a linkage between education and competencies pertaining to varied fields. Considering Cameroons vision of 2035, this study is timely in that it emphasizes the importance of competencies.

\section{METHODOLOGY}

\section{RESEARCH DESIGN}

The survey research design was adopted for the study. According to Nana (2008) a research design is a blueprint which gives a procedural outline on how data relating to a particular investigation should be collected and analysed. The study employed a questionnaire to collect the required data. An advantage of surveys is that they enable the researcher to collect data from many more subjects than would otherwise be possible. Furthermore, surveys are more economical than interviews (Amin, 2005).

\section{POPULATION OF THE STUDY}

The targeted population constitute randomly selected students of the first and second cycle (reunification batch) as well as some staff of the department of Administrative Techniques, civil engineering , Guidance Counselling and Tourism of the Higher Technical Teachers' Training College Kumba. The motive for this selection was to examined the used of capability approach in developing student teachers competences in technical sectors as a means to boost the emerging rate of Cameroon. HTTTC being a newly created school, if it must have a serious impact of industrialisation of Cameroon, freedom and capabilities of students must be considered serious. In this light, capability approach is adept for evaluation in this study.

\section{SAMPLE AND SAMPLING TECHNIQUE}

A sample is said to be a replica of the population under investigation with respect to certain characteristics that fit the investigation. It is often advisable to ensure that the population sampled is 
usually an accurate representation of the general population. Sample is particularly to eliminate bias, cost and to gain time within which the research is carried out. This study made use of purposive sampling method. The students of the reunification batch of Administrative Techniques, Civil engineering, computer Science, Guidance and counselling and Tourism as well as staffs are the main respondents. This is because the study is aimed at investigating the quality of competencies imbued in the student teachers patterning to the teaching skills. The study is limited to the Higher Technical Teachers' Training College Kumba in Meme Division, South West Region. The sample of the study was 200 students given that the population was 329 . This tie with sample required as stated by Krejcie \& Morgan (1970).

Table 1: Distribution of Sample by Departments

\begin{tabular}{|l|l|}
\hline \multicolumn{1}{|c|}{ Departments } & \multicolumn{2}{|c|}{ Sample } \\
\hline $\begin{array}{l}\text { Administrative } \\
\text { Techniques }\end{array}$ & 35 \\
\hline Civil Engineering & 40 \\
\hline Computer Science & 30 \\
\hline $\begin{array}{l}\text { Guidance And } \\
\text { Counselling }\end{array}$ & 40 \\
\hline Tourism & 200 \\
\hline Total & \\
\hline
\end{tabular}

Source; HTTTC Records (20 18)

\section{METHOD OF DATA COLLECTION AND RESEARCH INSTRUMENT}

The study exploits both the primary and secondary data. The secondary sources of data used in this study includes: books, articles and journals. The primary data is collected with the use of questionnaire and interviews. This study used the questionnaire to elicit information from the 200 respondents. Data was collected through the use of questionnaires and interview guide made up of open-ended (Likert-scale type of four response option items). The choice of a questionnaire was motivated by Gay and Airasion's (2000) with the motive that it is easier to collect data from respondents through the use of questionnaire because it requires less time, produces quick results, and also because it is cheaper.

The questionnaire in this study made use of the Likert scale to measure the level of competencies from the perspective of capability approach. Likert (1932) developed the principles of measuring attitudes by asking people respond to a series of statements about a topic in terms of the extent to which they agree or disagree with them, and so tapping into the cognitive and affective components of attitudes. According to Mcleod (2008), a Likert-type scale assumes that the strength of experience is linear, that is, on a continuum from strongly agrees to strongly disagree and makes the assumption that attitudes can be measured.

\section{INTERVIEW}

Interview guide was used in this study to authenticate the responses elicited from the questionnaire. The interview guide was designed by the researcher, given face and content validity by classmates and finally by the supervisor. As Kvale (1996) points out the main task in interviewing is to understand the meaning of what the interviewer says. Interview acts as a supporting agent, to add to the validation of responses collected through the use of other research instruments like questionnaires.

\section{VALIDATION AND RELIABILITY OF THE INSTRUMENT}

Validity and reliability was ascertained through input from colleagues, feedback from the supervisor as well as feedback from pilot testing of the questionnaire and interview guide within the master students of the Educational Foundations and Administration. After developing the two questionnaires, they were given to my classmates of the postgraduate programme for their input. They were expected to provide feedback on their suitability (clarity and fitness to research questions). Their feedback was used for revision after which they were given to the supervisor for his comments for further revision. After the supervisor's approval, the researcher carried out a pilot testing which involved a few students and lecturers who made up part of the population, but who were not included in the sample. Provision was made for their comments on the items. Few comments were made from students and supervisor and used in the modification of the items before the administration of the instrument.

\section{METHOD OF DATA ANALYSIS}

In Chapter four, collected data was analysed using the Statistical Package for the Social Sciences (SPSS version 21) and reported using measures of central tendency - frequencies, percentages, means, scores and global mean using the likert scale. Also, the study made used of the chi square test to test whether 
background indicators have any significant effect on teaching approaches. The spearman rank correlation was used to test the research hypothesis to establish the relationship between capabilities approach and the development of students' competences in HTTTC Kumba.

\section{FINDINGS}

Research Question One: What are the teaching and learning strategies implemented in the Higher Technical Teachers' Training College Kumba?

Table 4: Respondents' view on the Teaching and Learning Strategies implemented in the Higher Technical Teachers' Training College Kumba

\begin{tabular}{|c|c|c|c|c|c|}
\hline \multirow[t]{2}{*}{ ITEMS } & \multicolumn{2}{|c|}{ Agree } & \multicolumn{2}{|c|}{ Disagree } & \multirow[t]{2}{*}{$\mathbf{N}$} \\
\hline & $\mathrm{F}$ & $\%$ & $\mathrm{~F}$ & $\%$ & \\
\hline Students generate multiple ideas (Brainstorming) & 155 & 81.6 & 35 & 18.4 & 190 \\
\hline Students are able to exchange ideas (Group discussion) & 164 & 86.3 & 26 & 13.7 & 190 \\
\hline Students think logically and provide multiple answers (Brainstorming) & 160 & 84.2 & 30 & 15.8 & 190 \\
\hline Teachers perform activities for learners to observe (Demonstration) & 156 & 82.1 & 34 & 17.9 & 190 \\
\hline Students are able to transfer theory into practice (demonstration) & 131 & 69.0 & 59 & 31.1 & 190 \\
\hline $\begin{array}{l}\text { Two or more students develop a specific role and behave as the role } \\
\text { requires (Role play) }\end{array}$ & 147 & 77.4 & 43 & 22.6 & 190 \\
\hline $\begin{array}{l}\text { Students listen to Lecturers do presentations with the use of didactic } \\
\text { materials (Lecture/presentation ) International Journal }\end{array}$ & 80 & 42.1 & 110 & 57.9 & 190 \\
\hline MRS $\quad$ (2) of Trend in Scientific & 993 & 74.7 & 337 & 25.3 & 1330 \\
\hline
\end{tabular}

N/B: MRS stands for, "Multiple Response Set."

Source: Field Survey HTTTC Kumba (2016)

Research Question Two: What are the ways in which the Capability Approach is used in Developing Competences of Students of the Higher Technical Teachers' Training College Kumba?

Table 5: Ways used in implementing the Capability Approach in Developing Competences of Students in the Higher Technical Teachers' Training College Kumba?

\begin{tabular}{|l|l|l|l|l|l|}
\hline \multicolumn{1}{|c|}{ ITEMS } & \multicolumn{2}{|c|}{ Agree } & \multicolumn{2}{|c|}{ Disagree } & N \\
\cline { 2 - 7 } & $\mathrm{F}$ & $\%$ & $\mathrm{~F}$ & $\%$ & \\
\hline Students have freedom to do what they desire and they do it happily & 146 & 76.8 & 44 & 23.2 & 190 \\
\hline $\begin{array}{l}\text { Students are provided enough resources to make them obtain their } \\
\text { aspirations }\end{array}$ & 67 & 35.3 & 123 & 64.7 & 190 \\
\hline There are obstacles limiting students' abilities to achieve their desires & 151 & 79.5 & 39 & 20.5 & 190 \\
\hline $\begin{array}{l}\text { There is educational flexibility to encourage skill development and } \\
\text { creativity }\end{array}$ & 162 & 85.3 & 28 & 14.7 & 190 \\
\hline $\begin{array}{l}\text { Students are exposed to practical trainings and internships that drill } \\
\text { them into their professions }\end{array}$ & 105 & 55.3 & 85 & 44.7 & 190 \\
\hline Students are imposed certain things not valuable to their desires & 143 & 75.3 & 47 & 24.7 & 190 \\
\hline $\begin{array}{l}\text { The institution functions as a liberal system to promote freedom of } \\
\text { thought and action }\end{array}$ & 41 & 21.6 & 149 & 78.4 & 190 \\
\hline MRS & 815 & 61.3 & 515 & 38.7 & 330 \\
\hline
\end{tabular}

N/B: MRS stands for, "Multiple Response Set."

Source: Field Survey HTTTC Kumba (2016) 
International Journal of Trend in Scientific Research and Development (IJTSRD) ISSN: 2456-6470

Table 6: Students' Opinions on ways of implementing Capability Approach in Developing Competences by Background Indicators

\begin{tabular}{|c|c|c|c|c|c|c|c|}
\hline \multirow[t]{3}{*}{ Indicators } & \multirow[t]{3}{*}{ Categories } & \multicolumn{4}{|c|}{$\begin{array}{c}\text { Ways of using Capability } \\
\text { Approach in Developing } \\
\text { Competences }\end{array}$} & \multirow[t]{3}{*}{$\mathbf{N}=\mathbf{1 9 0}$} & \multirow[t]{3}{*}{ Chi-Square } \\
\hline & & \multicolumn{2}{|c|}{ Agree } & \multicolumn{2}{|c|}{ Disagree } & & \\
\hline & & $\mathbf{F}$ & $\%$ & $\mathbf{F}$ & $\%$ & & \\
\hline \multirow[t]{2}{*}{ Gender } & Male & 66 & 34.7 & 15 & 7.9 & 81 & \multirow{2}{*}{$\begin{array}{l}\chi 2=4.114 \\
\mathrm{P}=0.249\end{array}$} \\
\hline & Female & 96 & 50.5 & 13 & 6.8 & 109 & \\
\hline Age Group & $\begin{array}{l}20-25 \\
26-30 \\
31-35 \\
36 \text { and above }\end{array}$ & $\begin{array}{l}59 \\
2 \\
6 \\
0\end{array}$ & $\begin{array}{l}31.1 \\
1.1 \\
3.2 \\
0.0\end{array}$ & $\begin{array}{l}107 \\
3 \\
12 \\
1\end{array}$ & $\begin{array}{l}56.3 \\
1.6 \\
6.3 \\
0.5\end{array}$ & $\begin{array}{l}166 \\
5 \\
18 \\
1\end{array}$ & $\begin{array}{l}\chi 2=8.288 \\
\mathrm{P}=0.505\end{array}$ \\
\hline \multirow{6}{*}{$\begin{array}{l}\text { Highest educational } \\
\text { qualification }\end{array}$} & Advance level & 41 & 21.6 & 22 & 11.6 & 63 & \multirow{6}{*}{$\begin{array}{l}\chi 2=33.657 \\
P=0.001\end{array}$} \\
\hline & Degree & 55 & 28.9 & 8 & 4.2 & 63 & \\
\hline & DEPET I & 30 & 15.8 & 7 & 3.7 & 37 & \\
\hline & DEPET II in & $13 / 7$ & 6.8 & 2 & 1.1 & 15 & \\
\hline & Masters & 70 & 3.7 & 5 & 2.6 & 12 & \\
\hline & $\mathrm{PhD}$ & 0 & 0.0 & 0 & 0.0 & & \\
\hline \multirow[t]{5}{*}{ Domain of studies } & $\begin{array}{l}\text { Guidance and } \\
\text { Counselling }\end{array}$ & 22 & 11.6 & & 6.8 & 35 & \multirow[t]{5}{*}{$\begin{array}{l}\chi 2=10.827 \\
P=0.544\end{array}$} \\
\hline & $\begin{array}{l}\text { Administrative } \\
\text { Techniques }\end{array}$ & & 11.6 & 28 & 14.7 & 50 & \\
\hline & Civil Engineering & 23 & 12.1 & 12 & 6.3 & 35 & \\
\hline & $\begin{array}{l}\text { Computer rend } \\
\text { Sciences }\end{array}$ & $20 S \mathrm{C}$ & 10.5 & 15 & 7.9 & 35 & \\
\hline & Tourism & 18 & 9.5 & 17 & 8.9 & 35 & \\
\hline
\end{tabular}

\section{Source: Field Survey HTTTC Kumba (2016)}

Research Question Three: What are the Challenges faced in Developing Competencies of Student Teachers of the Higher Technical Teachers' Training College?

Table 7: Challenges faced in the Process of Developing Competencies of Student Teachers of the Higher Technical Teachers' Training College

\begin{tabular}{|c|c|c|c|c|c|}
\hline \multirow[t]{2}{*}{ ITEMS } & \multicolumn{2}{|c|}{ Agree } & \multicolumn{2}{|c|}{ Disagree } & \multirow[t]{2}{*}{$\mathbf{N}$} \\
\hline & $\mathrm{F}$ & $\%$ & $\mathrm{~F}$ & $\%$ & \\
\hline Inadequate teaching materials available for learning & 152 & 80.0 & 38 & 20.0 & 190 \\
\hline Students are not exposed to various teaching aids. & 92 & 48.4 & 98 & 51.6 & 190 \\
\hline $\begin{array}{l}\text { There is no proper supervision by the staffs to ensure } \\
\text { effectiveness. }\end{array}$ & 93 & 48.9 & 97 & 51.1 & 190 \\
\hline $\begin{array}{l}\text { There is no frequent visits nor follow-up from the administrators } \\
\text { to evaluate compliance to the approaches }\end{array}$ & 30 & 15.8 & 160 & 84.2 & 190 \\
\hline Unavailability of an equipped library & 158 & 83.2 & 32 & 16.8 & 190 \\
\hline Inadequate Laboratory for practical & 173 & 91.5 & 17 & 8.9 & 190 \\
\hline Insufficient teaching staff & 161 & 84.7 & 29 & 15.3 & 190 \\
\hline MRS & 939 & 70.6 & 391 & 29.4 & 330 \\
\hline
\end{tabular}

N/B: MRS stands for, "Multiple Response Set." 
International Journal of Trend in Scientific Research and Development (IJTSRD) ISSN: 2456-6470

Source: Field Survey HTTTC Kumba (2016)

Table 8: Students' Opinions on the Challenges faced in Developing Students' Competences by Background information

\begin{tabular}{|c|c|c|c|c|c|c|c|}
\hline \multirow[t]{3}{*}{ Indicators } & \multirow[t]{3}{*}{ Categories } & \multicolumn{4}{|c|}{$\begin{array}{l}\text { Views on Challenges in } \\
\text { Developing Competences }\end{array}$} & \multirow[t]{3}{*}{$\mathbf{N}=190$} & \multirow[t]{3}{*}{ Chi-Square } \\
\hline & & \multicolumn{2}{|c|}{ Agree } & \multicolumn{2}{|c|}{ Disagree } & & \\
\hline & & $\mathbf{F}$ & $\%$ & $\mathbf{F}$ & $\%$ & & \\
\hline \multirow[t]{2}{*}{ Gender } & Male & 44 & 23.2 & 37 & 19.5 & 81 & \multirow{2}{*}{$\begin{array}{l}\chi 2=2.999 \\
P=0.396\end{array}$} \\
\hline & Female & 49 & 25.8 & 60 & 31.6 & 109 & \\
\hline Age Group & $\begin{array}{l}20-25 \\
26-30 \\
31-35 \\
36 \text { and above }\end{array}$ & $\begin{array}{l}151 \\
5 \\
16 \\
1 \\
\end{array}$ & $\begin{array}{l}79.5 \\
2.6 \\
8.4 \\
0.5 \\
\end{array}$ & $\begin{array}{l}15 \\
0 \\
2 \\
0 \\
\end{array}$ & $\begin{array}{l}7.9 \\
0.0 \\
1.1 \\
0.0\end{array}$ & $\begin{array}{l}166 \\
5 \\
18 \\
1 \\
\end{array}$ & $\begin{array}{l}\chi 2=8.288 \\
P=0.505\end{array}$ \\
\hline \multirow{6}{*}{$\begin{array}{l}\text { Highest educational } \\
\text { qualification }\end{array}$} & Advance level & 61 & 32.1 & 2 & 1.0 & 63 & \multirow{6}{*}{$\begin{array}{l}\chi 2=18.445 \\
P=0.103\end{array}$} \\
\hline & Degree & 58 & 30.5 & 5 & 2.6 & 63 & \\
\hline & DEPET I & 30 & 15.8 & 7 & 3.7 & 37 & \\
\hline & DEPET II $S \mathrm{C}$ & 14 & 7.4 & 1 & .5 & 15 & \\
\hline & Masters & 10 & 5.3 & 2 & 1.0 & 12 & \\
\hline & $\mathrm{PhD}$ & 0 & 0.0 & 0 & 0.0 & & \\
\hline \multirow[t]{5}{*}{ Domain of studies } & $\begin{array}{l}\text { Guidance and } \\
\text { Counselling }\end{array}$ & 30 & 15.8 & & 2.6 & 35 & \multirow{5}{*}{$\begin{array}{l}\chi 2=14.664 \\
P=0.260\end{array}$} \\
\hline & $\begin{array}{l}\text { Administrative } \\
\text { Techniques }\end{array}$ & 45 & 23.7 & 5 & 2.6 & 50 & \\
\hline & Civil Engineering & 26 & 13.7 & 9 & 4.7 & 35 & \\
\hline & $\begin{array}{l}\text { Computer rend } \\
\text { Sciences }\end{array}$ & $28 \mathrm{CC}$ & 14.7 & 7 & 3.7 & 35 & \\
\hline & Tourism Resea & 2911 & 15.3 & 6 & 3.2 & 35 & \\
\hline
\end{tabular}

Source: Field Survey HTTTC Kumba (2016)

Summary of Findings Table

\section{Research Questions}

1: What are the teaching and learning strategies implemented in the Higher Technical Teachers' Training College Kumba?

2: What are the ways in which the Capability Approach is used in Developing Competencies of Students in the Higher Technical Teachers' Training College Kumba?

3: What are the Challenges faced by both students and teachers in Developing Competencies of at the Higher Technical Teachers' Training College, Kumba?
Findings

Teachers highly make use of group discussion, brainstorming and demonstration approaches, while role play and Lecture/presentation approaches are used but in a limited way as comparatively.

Students choose their options

Students are offered freedom of belonging to discussion groups

Students go out for internship and teaching practice There is supervision from the administrators

Inadequate teaching materials, poorly equipped libraries, inadequate laboratory for practical and insufficient teaching staff.

In a similar manner, teachers face the problem of inadequate training materials, complexity of teaching/learning approach, limited time, none payment of part time instructors, insufficient teachers in schools and much work load. 


\section{Null Hypothesis: There is a no significant relationship between capability approach and the development of competencies.}

There is a strong positive relationship between the use of the capability approach and the development of competences of students of HTTTC Kumba. The value of the correlation is 0.586 which is positive.

\section{Educational Implication And Recommendations}

From the findings and conclusion drawn above, the following educational implications and recommendations can be deduced based on the objectives of the study to students, parents, teachers, stakeholders and even the government including the pedagogic inspectors.

This study found that most teachers use the group discussion strategy which gives a burden of learning on the students and can be timeconsuming. Also, its success relies on learner preparation and willingness to participate and can lead to a dominant few controlling the floor to the exclusion of fuller participation. Hence, it was suggested that since this method cannot ensure full participation within the group, teachers should develop group facilitation skills to manage the interactions, time, and process effectively, paying attention to both task and group interaction functions. The study also found that lecture presentation and role play is not mostly used. It is recommended that lecturers should use a great deal of role play and employ modern methods of presentation such as the use of projectors and videos to increase understanding and better skills development.

$>$ Secondly, the findings show that brainstorming is also highly practiced in the HTTTC Kumba which is a method in which judgment is suspended until a maximum number of ideas have been generated. This method could not be very effective with large groups and given that it is a school setting and that teachers complain of work load with respect to class size, it can be recommended that teachers should provide clear instructions for how the process works and ensure that participants adhere to the rules before this strategy can be reliable.

$>$ With respect to the demonstration method, it was recommended that teachers should endeavour to keep the demonstration simple and the explanation thorough enough to meet learners' objectives. They should also give learners an opportunity to practice what has been demonstrated if not the development of their competencies might be difficult to come about.
Lecture method was identified to be the least practiced teaching method in the HTTTC Kumba. As such, the study recommended that though it can be an effective means of providing new information and clarifying existing information to a large heterogeneous group in a short period of time, it can be disadvantaged in that it has very limited effectiveness in teaching anything other than knowledge and it can lead to boredom. Hence, it could be recommended that for the method to be effective teachers should develop quality supporting audiovisual aids and know how to use them and any needed equipment; avoid overloading slides with information and talking to a screen rather than to learners.

This study equally revealed that the capability approach is implemented in the HTTTC Kumba in which students are given some freedom to do what they desire and as such, they do so better. It could be recommended that teachers should apply this capability approach with caution to ensure that students do not misuse the freedom they are offered.

Also, given that competencies development is an activity whose success involves both the learners and the teachers, and students are the ones to benefit from them, they should endeavour to collaborate with their teachers and parents back at home in order to encourage them dedicate time to teach them well, and even apply this capability approach by making available their text books to ensure proper learning. Also they should always try to take their studies seriously both in and out of the school premises. This will enable them to properly channel their problems to the administrators on the difficulties they are facing in learning.

Teachers need to be continuously trained through seminars and workshops as well as regular follow up by authorities and pedagogic inspectors to ensure that the teaching learning methods are properly implemented and also address the problems both teachers and students face in school.

To the Directors of studies, they should know that they are the supervisory authorities in any school milieu and can be the only ones to systematically 
evaluate the implementation of the teaching and learning methods applicable in the school including the capability approach. They should also endeavour to maintain a cordial relationship between them and their teachers as well as their students because it is a prerequisite for appropriate teaching and learning.

$>$ Based on Sen's theory of freedom and the ability to do what an individual desires, recommendations have also been drawn from a conference report presented by Ralph Tyler attended and reported by (Ntui, 1991). In the conference's report (eight annual assistant Principals of conference) co-sponsored by Georgia Southern University's department of educational leadership, the following can help enhance competencies development in technical education in Cameroon:

$>$ The entire educational enterprise should move from bureaucratised, hierarchical, regimented and rule bound to a flexible enterprise as stated in the conference report and supported by Sen's theory of capability approach on freedom.

$>$ The organisation management's general principle says that teachers are (human resources) put where needs are more urgent. If technical training is more urgent in Cameroon now, then more permanent teachers should be recruited in the Higher Technical Training Institutions.

$>$ Technical institutions should focus teaching in the next ten years on where the problems aretechnical education should be problem solving not memorization.

$>$ Industrial departments can introduce a toolacquisition scheme in order to be more functioning. This study also recommends that the Technical Education in Cameroon should move away from measuring skill development and acquisition through the number of students that pass exams but should ensure that a major focus should be in terms of students' abilities to meet the needs of the job market. This could be done by ensuring that students spend more time during industrial placement to acquire practical skills and competences that meet the needs of the job market. Also, lecturers should do frequent followup on students on internship to ensure that there is effectiveness in competences acquisition.

$>$ According to capability, freedom couple with abilities will lead to optimum efficiency on human being. Base on this, this study recommend that the government should give lecturers freedom in taking decisions pertaining to the quality of education as this will enable them take decisions that meets the needs of the job market rather than government officials. In this light, technical educational courses will be tailor to the needs of economy and educational institutions should consider developing skills that meet the needs of the region.

Lastly, the study revealed that the highest problem limiting the proper development of students' competencies is the lack of resources to both learners and teachers such as, textbooks, libraries and even laboratories. As such, it could be suggested that the school authority should channel the issue to the authority in charge so that the objective of becoming Emergence by the year 2035 can be obtainable.

\section{CONCLUDING REMARKS}

This study sought to examine the capability approach and the development of competencies of Students of the Higher Technical Teachers' Training College Kumba. Data was collected from students of the school using a questionnaire and an interviewed conducted with some few teachers of the school. The study had as specific objectives to identify the teaching and learning strategies used in this school, examine the use of the Capability approach in the development of competencies of students and the challenges faced by both the students and teachers in the implementation of the capability approach in developing competencies in the Higher Technical Teachers' Training College Kumba.

From the results obtained, teachers of the HTTTC Kumba highly implement group discussion, brainstorming and demonstration while role played and lecture/presentation methods are only implemented to a lesser extent. In terms of the implementation of the capability approach, teachers of HTTTC Kumba apply the capability approach but for the fact that resources are insufficient to facilitate the effective implementation of this approach. Despite this, the value of the correlation is 0.586 which is positive indicating a strong positive relationship between the use of the capability approach and the development of students' competencies in HTTTC Kumba. It was then established that there was statistically enough evidence to emphasize on the capability approach and the development of students 
competences in HTTTC Kumba because $\mathrm{r}=0.586$, $\mathrm{P}=0.001$.

As such, it was concluded in favour of Sen's findings that Technical education today is the most valuable means by which the quality of a country's development is determined. This is because capable people are more likely to be able to deal effectively with the turbulent environment in which they live by possessing this 'all round' capacity. Also, the focus of the capability approach lies in the freedom that a person actually has; not merely in the evaluation of the situation by an external body.

This contradicts DeSeCo report which alludes to issues like "Human Rights", "Sustainability" or "Democracy" that they are understood as the result of the education process, not as the essential justification for the specific core competencies. This means that the report does not consider human rights or democratic values as a basic reason for developing the competencies; the basic reasons are instrumental, utilitarian and adaptive. The important practical point to stress here however is that the development of core competences could lead, as a secondary effect, to a more sustainable and democratic society. As such, inferences was drawn that for Cameroon to become Emerging by the year 2035 competency development in Technical Education need to be given adequate attention. This is so to the extent that (Walker, 2003; Boni \& Lozano, 2007) stated that the notion of competence and skills is guiding the development of undergraduate and postgraduate syllabuses throughout the process of building a common technical Education Area.

\section{REFERENCES}

1) Agbor M. N. (1991, July). Understanding and affecting the Past fifty Years of Education. A paper presented the $8^{\text {th }}$ Annual Assistant principal Co-sponsored by Georgia Southern University's Department of Educational Leadership.

2) Bangkok, August. Cohen, S.G. \& Ledford, S.G. (1994) 'The effectiveness of self managing teams: A quasi-experiment', Human Relations, 47(1), pp $13-43$

3) Becker, G.S. (1975), Human Capital: A Theoretical and Empirical Analysis with Special Reference to Education (2nd ed.). Chicago: University of Chicago Press.
4) Cochran-Smith, Marilyn (2001) 'Constructing Outcomes in Teacher Education: Policy, Practice and Pitfalls', in: Education Policy Analysis Archives, Vol. 9, No. 2.

5) Crocker, D. A. and I. Robeyns, (2009) "Capability and agency" in: Christopher Morris (ed.), The Philosophy of Amartya Sen, Cambridge University Press, 2009, pp. 60-90.

6) Crocker, D. A., (2008). Ethics of Global Development: Agency, Capability and Deliberative Democracy, Cambridge: Cambridge University Press.

7) Deininger, K. (2000), Does cost of schooling affect enrolment by the poor? Universal primary education in Uganda. Economics of Education Review. Vol. 22, pp. 291-305.

8) Fosnot ,C.T., (1996), Constructivism: Theory, Perspective and Practice, Teachers College Press, New York. Graves, N. (ed) (1993) Learner Managed Learning: Practice, Theory and Policy, WEF and HEC, Leeds. Hase, S. (1998) ' Workbased learning for learning organisations', in Stephenson, J. \& Yorke, M. (eds) Capability and Quality in Higher Education, Kogan Page, London.

9) Freeman, S., (2006). Book review-Frontiers of Justice: The capabilities approach versus contractarianism. Texas Law Review 85(2): 385430 .

10) Fukuda-Parr, S. (2003) "The Human Development Paradigm: operationalizing Sen's ideas on development", Feminist Economics, 9(2/3): 301317.

11) Fukuda-Parr, S. and Kumar S. (2009). Handbook of Human Development: Concepts, Measures and Policies, Delhi: Oxford University Press.

12) Gay, L. R. \& Arasian, P. (2000). Educational Research: Competences for analysis and application. $\left(6^{\text {th }}\right.$ ed.). New Jersey: Prentice Hall, Inc

13) Gordon, C. (2002). Developing deep learning approaches and personal teaching efficacy within a pre service teacher education context.

14) Hase, S., Cairns, L. G. and Malloch, M. (1998) Capable Organisations: The Implications for Vocational Education and Training, ANTA, 
International Journal of Trend in Scientific Research and Development (IJTSRD) ISSN: 2456-6470

15) Hoffman, A. M. (2006), The Capability Approach and educational policies and strategies: effective life skills education for sustainable development, Paris: Agence Française du Dévelopement (AFD).

16) Hoffmann, A.M., K. Radja \& P. Bakhshi (2008).Education and Capabilities Approach: Life Skills Education as A Bridge to Human Capabilities

17) Mbua, F. N. (2003). Educational Administration: Theory and Practice. Design House; Press print Ltd., limbe

18) Mbua, F.N. (2002). Educational Planning: Issues and Perspectives. Presprint Plc, Limbe.

19) McCowan, T. (2011), Human rights, capabilities and the normative basis of 'Education for All'. Theory and Research in Education. Vol. 9, No. 3, pp. 283-298.

20) Mcleod, J. (2008). Outside the therapy room. In C. Back (Ed.) Veiledernettverket: University of agderPress.

21) McMillan, L. K., (2011). What's in a right? Two variations for interpreting the right to education. International Review of Education. Vol. 56, no. 56, pp.531-545.

22) Nana, C. (2008). Research and statistical analyses; A practical guide for applied statistics using SPSS. Buea: GOODHEAD \& FASTDAM

23) Ninsiima, A. (2007). Investigating the role of "resources" in enhancing women's agency, freedom and empowerment? Uganda's Experience. Human Development and Capability Association. Conference Paper.

24) Nussbaum, Martha (2011), Creating capabilities. The Human Development approach, Cambridge, The Belknap Press of Harvard University Press

25) Nussbaum, Martha C. (2000). Women and Human Development: The Capabilities Approach. Cambridge University Press, Cambridge.

26) Robeyns, I. (2006).Three Models of Education: rights, Capabilities and Human Capital. Theory and Research in Education. Vol. 4, No. 1, pp. 6984.

27) Robeyns, I., (2003) "Sen's Capability Approach and Gender Inequality: Selecting Relevant Capabilities," Feminist Economics, 9(2/3): 61-92.

28) Saito, M. (2003), Amartya Sen's Capability Approach to Education: A Critical Exploration.
Journal of Philosophy of Education, Vol. 37, No. 1, 2003, pp. 17-33.

29) Sewamala, F. M. et al. (2011), Strengthening Universal Primary Education in Uganda: The potential role of an asset-based development policy. International Journal of Educational Development. Vol. 31, pp. 472-477.

30) Spoelder, M.W. (2009). The Conceptualization of Quality Education in Zambia. Dissertation MA Education \& International Development. Institute of Education, University of London

31) Spoelder, M.W. (2010), The Conceptualization of Quality Education in Zambia. Dissertation Summary Paper. MA Education and International Development. Institute of Education, University of London.

32) Stephens, D. (2003), Quality of Basic Education. Background paper prepared for the Education for All Global Monitoring Report 2003/4. Gender and Education for All: The Leap to Equality

33) Unterhalter, E. (2002), "The Capabilities Approach al and Gendered Education: An Examination of South African Complexities", in Theory and Research in Education, 1, 7-22.

34) Weisen, R.B., Lee, J., \& Pellaux, D. (1995), Life Skills Education as a Component of a Comprehensive School Health Program, WHO, Geneva. 